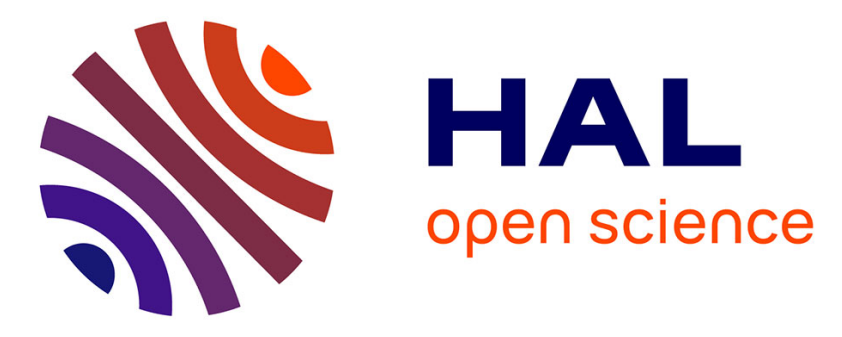

\title{
Inhibitory effect of cadmium on estrogen signaling in zebrafish brain and protection by zinc
}

Lina Chouchene, Elisabeth Pellegrini, Marie-Madeleine Gueguen, Nathalie Hinfray, François Brion, Benjamin Piccini, Olivier Kah, Khaled Saïd, Imed Messaoudi, Farzad Pakdel

\section{To cite this version:}

Lina Chouchene, Elisabeth Pellegrini, Marie-Madeleine Gueguen, Nathalie Hinfray, François Brion, et al.. Inhibitory effect of cadmium on estrogen signaling in zebrafish brain and protection by zinc. Journal of Applied Toxicology, 2016, 36 (6), pp.863-871. 10.1002/jat.3285 . hal-01274217

\section{HAL Id: hal-01274217 https://hal-univ-rennes1.archives-ouvertes.fr/hal-01274217}

Submitted on 2 May 2016

HAL is a multi-disciplinary open access archive for the deposit and dissemination of scientific research documents, whether they are published or not. The documents may come from teaching and research institutions in France or abroad, or from public or private research centers.
L'archive ouverte pluridisciplinaire HAL, est destinée au dépôt et à la diffusion de documents scientifiques de niveau recherche, publiés ou non, émanant des établissements d'enseignement et de recherche français ou étrangers, des laboratoires publics ou privés. 


\title{
Inhibitory effect of Cadmium on estrogen signaling in zebrafish brain and protection by Zinc
}

\author{
Lina Chouchene', Elisabeth Pellegrini' ${ }^{2}$, Marie-Madeleine Gueguen ${ }^{2}$, Nathalie Hinfray ${ }^{3}$, \\ François Brion ${ }^{3}$, Benjamin Piccini ${ }^{3}$, Olivier Kah $^{2}$, Khaled Saïd ${ }^{1}$, Imed Messaoudi', \\ Farzad Pakdel ${ }^{4 *}$
}

1 Génétique, Biodiversité et Valorization des Bioressources, Université de Monastir, Institut Supérieur de Biotechnologie de Monastir, Tunisia.

2 Neuroendocrine Effects of Endocrine Disruptors, University of Rennes 1, Campus de Beaulieu, France.

3 Unité d'Ecotoxicologie in vitro et in vivo, Direction des Risques Chroniques, Institut National de l'Environnement Industriel et des Risques (INERIS), Verneuil-en-Halatte, France.

${ }^{4}$ Transcription, Environnement et Cancer, Institut de Recherche en Santé-EnvironnementTravail (Irset), Inserm UMR 1085, Université de Rennes 1, France.

* To whom correspondence should be addressed at team "Transcription, Environnement et Cancer", Institut de Recherche en Santé-Environnement-Travail (Irset), Inserm UMR 1085, Université de Rennes 1, 35042 Rennes cedex, France. E-mail: farzad.pakdel@univ-rennes1.fr

\section{Abstract}

The present study was conducted to assess the effects of cadmium (Cd) exposure on the estrogen signaling in the zebrafish brain, as well as the potential protective role of zinc ( $\mathrm{Zn}$ ) against $\mathrm{Cd}$-induced toxicity. For this purpose, effects on the transcriptional activation of estrogen receptors (ERs), aromatase B (Aro-B) protein expression and molecular expression of related genes were examined in vivo using wild-type and transgenic zebrafish embryos. For in vitro studies, an ER-negative glial cell line (U252-MG) transfected with different zfER subtypes (ER $\alpha, E R \beta 1$ and ER $\beta 2)$ was also used. Embryos were exposed either to estradiol (E2), Cd, E2+Cd or E2+Cd+Zn for 72 hours and cells were exposed to the same treatments for 30 hours. Our results show that E2-treatment promoted the transcriptional activation of ERs and increased Aro-B expression, at both the protein and mRNA levels. Although exposure to $\mathrm{Cd}$, does not affect the studied parameters when administered alone, it significantly abolished the E2-stimulated transcriptional response of the reporter gene for the three ER subtypes in U251-MG cells, and clearly inhibited the E2-induction of Aro-B in radial glial cells of zebrafish embryos. These inhibitory effects were accompanied with a significant down-regulation of the expression of esrl, esr $2 a$, esr $2 b$ and cyp19alb genes compared to the E2-treated group used as a positive control. $\mathrm{Zn}$ administration during simultaneous exposure to $\mathrm{E} 2$ and Cd strongly stimulated zfERs transactivation and increased Aro-B protein expression, whereas mRNA levels of the three ERs as well as the cyp19a1b remained unchanged in comparison with Cd-treated embryos. In conclusion, our results 
clearly demonstrate that $\mathrm{Cd}$ acts as a potent anti-estrogen in vivo and in vitro, and that $\mathrm{Cd}-$ induced E2 antagonism can be reversed, at the protein level, by $\mathrm{Zn}$ supplement.

Keywords: Cadmium, Estradiol, Zinc, Estrogen receptor, Aromatase

\section{Short Abstract for Table of Contents}

This study was conducted to assess the effects of cadmium (Cd) exposure on the estrogen signaling in the zebrafish brain, and the potential protective role of zinc $(\mathrm{Zn})$ against $\mathrm{Cd}$ induced toxicity. Effects on the transcriptional activation of estrogen receptors, aromatase $\mathrm{B}$ protein expression and molecular expression of related genes were examined.Our results demonstrate that $\mathrm{Cd}$ acts as a potent anti-estrogen in vivo and in vitro, and that $\mathrm{Cd}$-induced estradiol antagonism can be reversed, at the protein level, by $\mathrm{Zn}$ supplement.

\section{Introduction}

Cadmium $(\mathrm{Cd})$ is a widespread environmental toxicant that harmfully affects humans and animals. Its effects as an endocrine disruptor (ED) have been extensively documented. This metal can act by altering the homeostatic balance of a variety of hormones in both mammals (Lafuente et al., 2003 ; Piasek and Laskey, 1999 ; Piasek et al., 2001) and fish (Kime, 1984 ; Mukherjee et al., 1994). Gonadal damage and interference with gametogenesis were also observed after $\mathrm{Cd}$ exposure. In testis, $\mathrm{Cd}$ can cause hemorrhagic necrosis (Parizek and Zahor, 1956 ; Thompson and Bannigan, 2008) and reduced sperm count (Amara et al., 2008), whereas in ovaries, it increases the proportion of atretic follicles, reduces the number of vitellogenic oocytes and decreases yolk formation (Chouchene et al., 2011). Several other studies have also associated $\mathrm{Cd}$ with a wide range of reproductive disorders, including growth retardation, sterility and embryotoxicity (Fahmy and Aly, 2000).

While the effects of $\mathrm{Cd}$ on the endocrine system and its potential deleterious effects on living organisms are no longer in doubt, the underlying mode of actions remained unclear. However, many of the toxic effects of $\mathrm{Cd}$ have been suggested to result from interaction with essential elements, such as zinc (Zn) (Brzóska and Moniuszko-Jakoniuk, 2001 ; Lansdown et al., 2001 ; Waalkes, 1986), via the mechanism of ionic mimicry (Bridges and Zalups, 2005). Zn is a trace element of great importance for the organism, involved in many metabolic processes and well known as a $\mathrm{Cd}$ antagonist. Indeed, numerous studies have shown that $\mathrm{Zn}$ strongly reversed Cd-induced toxicity in various organs and tissues such as liver (Banni et al., 2011), kidney (El Heni et al., 2010), blood (Jemai et al., 2007) and testis (Messaoudi et al., 2010). Using adult female zebrafish, we have recently reported similar results in the ovarian tissue (Chouchene et al., 2011). Zn treatment during $\mathrm{Cd}$ exposure reversed Cd-induced $\mathrm{Zn}$ depletion, as well as $\mathrm{Cd}$ and metallothionein accumulation, thus reducing ovarian histopathological damages (Chouchene et al., 2011). Cd has been shown to exert its toxicity by disturbing $\mathrm{Zn}$ uptake via changes in the gene expression pattern of $\mathrm{Zn}$ transporters, mainly by downregulating ZnT1 (as exporter) and overexpressing ZIP10 (as importer). We also concluded that the improving effects of dietary Zn supplementation on Cd-induced toxicity are mediated, in part, by the increase of $\mathrm{Zn}$ availability and subsequently the induction of 
ZnT1 gene expression. These results in ovary have prompted us to further investigate the effect of these compounds in the endocrine system and especially on estrogen signaling.

Estradiol (E2) is a female sexual steroid best known for its roles in reproductive functions. This hormone exerts crucial effects on the development and functioning of the gonadotropic axis at the level of the gonads, pituitary and brain (Carreau, 2002). Its actions are mediated by the estrogen receptor (ER), a member of the superfamily of nuclear receptors, acting as ligand-dependent transcription factors (Moggs and Orphanides, 2001). ER is composed of three functional domains: the N-terminal domain involved in transcriptional activation of gene expression; the DNA-binding domain (DBD) thought to coordinate two $\mathrm{Zn}$ ions with cysteine residues into $\mathrm{Zn}$ finger motifs; and the C-terminal domain carrying the ligandbinding domain (LBD) (Evans, 1988 ; Pike, 2006). Upon E2 binding, ER dimerizes so that it may bind to specific DNA sequences called estrogen responsive elements (EREs) and may stimulate the transcription of specific genes (Kerdivel et al., 2013). A number of studies demonstrated that $\mathrm{Cd}$ can mimic the effects of $\mathrm{E} 2$ in rats and estrogen-responsive breast cancer cell line (MCF-7) (Johnson et al., 2003 ; Martin et al., 2003 ; Stoica et al., 2000), whereas other groups reported a lack of estrogenicity and an inhibitory effect of this heavy metal on E2-induced reporter activity and cell proliferation (Le Guével et al., 2000 ; Silva et al., 2006).

Since $\mathrm{Zn}$ is well known to protect against $\mathrm{Cd}$ toxicity in many tissues, as previously documented, we wondered if this oligoelement could have an effect on reversing Cd-agonism or antagonism versus E2. To our knowledge, there is no information regarding the effects of combined exposure to $\mathrm{Cd}$ and $\mathrm{Zn}$ on estrogen signaling. Therefore, the present work was undertaken to investigate the estrogenic or anti-estrogenic potency of $\mathrm{Cd}$ and the ability of $\mathrm{Zn}$ to reverse Cd-induced toxicity in zebrafish. Both in vivo and in vitro approaches were combined in order to obtain a better understanding of the molecular actions of $\mathrm{Cd}$. For this, wild-type and transgenic zebrafish were used, as well as a cell-based transcription assay based on an ER-negative glial cell line U251-MG transfected with ER subtypes and an E2responsive reporter gene. First, the impact of several concentrations of $\mathrm{Cd}$ and $\mathrm{Zn}$, alone or in mixture with E2, on the transcriptional activity of the three distinct zebrafish ERs (zfERs) was tested, as well as the molecular expression of the related genes. Second, the effects of Cd alone or in combination with $\mathrm{Zn}$ were monitored, upon E2-treatment, on the expression of an estrogen-sensitive gene, cyp19alb, that encodes brain aromatase (Aro-B) in fish (Diotel et al., 2010).

\section{Materials and methods}

\section{In vitro experiments}

\section{Cell culture and transient transfection}

Human astrocyte U251-MG cells (ECACC) were maintained at $37^{\circ} \mathrm{C}$ under a $5 \% \mathrm{CO} 2$ humidified atmosphere in Dulbecco's modified Eagle medium (DMEM; Gibco) supplemented with $10 \%$ fetal calf serum (FCS, Biowest) and $1 \%$ antibiotic (penicillin/streptomycin). One day before transfection, cells were washed and seeded in fresh medium on 24-well plates at a density of $0.2 \times 10^{5}$ cells $/ \mathrm{ml}$. After 24 hours, the medium was replaced with fresh phenol red-free DMEM containing 2.5\% FCS. Transient transfections of U251-MG cells were carried out with plasmid-DNA using JetPEI ${ }^{\mathrm{TM}}$ reagent, as indicated by the manufacturer (Polyplus-transfection, France). The DNA templates contained $50 \mathrm{ng}$ of 
zebrafish estrogen receptor expression vector (esr1, esr2a, and esr $2 b$ ), $150 \mathrm{ng}$ of ERE-TK-Luc reporter plasmid and $25 \mathrm{ng}$ of internal $\beta$-galactosidase control vector (cytomegalovirus $[C M V]-\beta$-gal). Following an overnight incubation, cells were replaced in fresh DMEM 2,5\% desteroided FCS medium and treated during 30 hours with either $17 \beta$-estradiol $\left(10^{-9} \mathrm{M}\right.$; Sigma, St. Louis, MO), cadmium chloride $\left(\mathrm{CdCl}_{2}\right.$, Fluka 20899), zinc chloride $\left(\mathrm{ZnCl}_{2}\right.$, LOBA Chemie 280410), E2 $+\mathrm{Cd}$, or E2 $+\mathrm{Cd}+\mathrm{Zn}$. Dose-response experiments for $\mathrm{Cd}\left(10^{-8}\right.$ $\mathrm{M}$ to $\left.10^{-5} \mathrm{M}\right)$ and $\mathrm{Zn}\left(10^{-9} \mathrm{M}\right.$ to $\left.10^{-5} \mathrm{M}\right)$ were performed in order to determine the $\mathrm{Cd}$ concentration that inhibited $50 \%$ of the $\mathrm{E} 2$ effect $\left(\mathrm{IC}_{50}\right)$ and the effective concentration of $\mathrm{Zn}$. Ethanol $(\mathrm{EtOH})$ was used as a vehicle.

Cells were lysed 48 hours later using a luciferase assay system (Promega, France). The reporter gene activity was quantified from the luciferase activity with Veritas Luminometer (Turner biosystems) and then the absorbance of the $\beta$-galactosidase activity was determined with iMark microplate reader (Biorad). The luciferase activity was then normalized by $\beta$ galactosidase activity and expressed as fold induction relative to control group (EtOH). All transfections were performed in triplicate in at least three independent experiments.

\section{Plasmids}

Expression vector-encoding regions of zebrafish esrl, esr $2 a$, and esr $2 b$, respectively for zfER $\alpha$, zfER $\beta 1$ and zfER $\beta 2$, were previously described (Menuet et al., 2002), as well as the estrogen response element (ERE)-thymidine kinase-luciferase (ERE-TK-luc) and $C M V$ - $\beta$-gal reporter plasmids (Métivier et al., 2002). The plasmid $C M V$ - $\beta$-gal was used for the normalization of the transfection efficiency and the cytomegalovirus promoter led independent the expression of the $\beta$-galactosidase enzyme.

\section{In vivo experiments}

\section{Ethics}

This study was approved by the ethics committees INERIS (Institut National de l'Environnement Industriel et des Risques) and CREEA (Comité Rennais d'Ethique en matière d'Expérimentation Animale) under permit number EEA B-35-040. All steps have been taken to reduce suffering of animals. Experiments were performed in accordance with the European Union regulations concerning the protection of experimental animals (Directive 86/609/EEC).

\section{Animals and treatments}

Experiments were performed on wild-type and transgenic (cyp19alb-GFP line) (Tong et al., 2009) zebrafish (Danio rerio). Animals were housed in the Biosit zebrafish facility (INRA, LPGP, Rennes, France) and were treated in agreement with the European Union regulations concerning the protection of experimental animals. Immediately after spawning, zebrafish eggs were divided into seven groups. Two groups were used as controls and were treated with distilled water for the first group and ethanol $(\mathrm{EtOH})$ for the second one. The remaining five experimental groups were treated either with $\mathrm{E} 2\left(10^{-9} \mathrm{M}\right), \mathrm{Cd}\left(10^{-6} \mathrm{M}\right.$ as $\left.\mathrm{CdCl}_{2}\right), \mathrm{Zn}\left(10^{-5} \mathrm{M}\right.$ as $\left.\mathrm{ZnCl}_{2}\right), \mathrm{E} 2+\mathrm{Cd}\left(\mathrm{E} 210^{-9} \mathrm{M}+\mathrm{Cd} 10^{-6} \mathrm{M}\right)$, or E2 + Cd + Zn $\left(\mathrm{E} 210^{-9} \mathrm{M}+\mathrm{Cd} 10^{-6} \mathrm{M}+\mathrm{Zn} 10^{-5}\right.$ $\mathrm{M})$. In all conditions, 80 and 20 eggs, respectively, for wild-type and transgenic zebrafish line, were treated for 72 hours in Petri dishes at $28.5^{\circ} \mathrm{C}$. The chemicals were renewed every 24 hours. Each substance was tested at least in three independent experiments. 


\section{Aromatase B immunohistochemistry}

After 72 hours of treatment, wild-type and transgenic embryos were fixed overnight at $4{ }^{\circ} \mathrm{C}$ in a saline phosphate buffer (PBS, $\mathrm{pH}$ 7.4) containing 4\% paraformaldehyde (Sigma), and then immersed in sucrose. Samples were embedded in Tissue-Tek (Neg 50, Thermo Scientific, France) and the entire head was then processed for cryostat sections ( $8 \mu \mathrm{m}$ of thickness).

Immunohistochemistry experiments were performed on the brain of wild-type embryos. Tissue sections were first rinsed in PBS 1X, and then nonspecific binding was blocked for 1 hour at room temperature in PBS containing $0.2 \%$ Triton and $0.5 \%$ milk powder. Sections were then incubated with a specific affinity-purified antibody directed against zebrafish aromatase B (Menuet et al., 2005 ; Pellegrini et al., 2007) diluted 1:800. Slides were kept overnight at room temperature in a humidified chamber. After three washes in PBS $0.2 \%$ Triton, tissue sections were incubated with the appropriate secondary antibody (Goat anti rabbit Alexa 594, 1:500 in PBS containing 0.5\% milk) for 2 hours before washing in PBS. At the end of the immunohistochemistry protocol, sections were mounted on glass slides in Vectashield containing 4',6-diamidino-2-phenylindole (DAPI) counterstaining (Vector, USA). Brain sections of wild-type and transgenic zebrafish embryos, obtained from three independent exposure experiments performed in duplicate, were then observed with an

Olympus Provis microscope equipped with a digital camera. Images were obtained with the Olympus Cell software.

\section{RNA Extraction and Reverse Transcription}

Following 72 hours of treatment, pools of wild-type embryos (50) exposed to the same treatment were rapidly frozen and total RNA was extracted using the Trizol reagent (Invitrogen) by sonication. Reverse transcription was performed in presence of Moloney Murine Leukemia Virus Reverse Transcriptase (MMLV-RT) according to the manufacturer's procedure (Promega). Briefly, two micrograms of total RNA were reverse transcribed for 1 hours at $37^{\circ} \mathrm{C}$ in $25 \mu \mathrm{l}$ reaction mixture containing $0.5 \mu \mathrm{g}$ random hexamers (Promega, France), $25 \mathrm{mM}$ dNTPs, 5X MMLV-RT buffer, and $50 \mathrm{U}$ MMLV-RT (Promega).

\section{Quantitative Real-Time polymerase chain reaction}

Quantitative polymerase chain reaction (qPCR) was carried out on an iCycler MyiQ (BioRad, France) using iQ SYBR Green supermix (Bio-Rad). The primers used are shown in Table 1. In our laboratory, we have previously shown that the most commonly used reference genes including $\beta$-actin, GAPDH and RNA 18S, classically used for standardization in such experiments, showed variations during zebrafish development (Mouriec et al., 2009b). However, the elongation factor 1 (EF1) was found to be appropriate for normalisation in zebrafish embryos since its expression was not affected by treatments and remained stable in control and treated embryos (Mouriec et al., 2009a). Therefore, the efl gene was chosen to normalize the expression levels of the mRNAs. Samples not exposed to reverse transcriptase were used as negative control to monitor DNA contamination. Specific amplification of single products was controlled by performing melting curves and analysing PCR efficiency. PCR reactions were run at least in triplicate. The MyiQ (version 1.0) optical system software (Bio$\mathrm{Rad})$ was used to analyze PCR amplifications. Results were expressed according to the $\mathrm{Ct}$ method (ddCt) for relative quantification of gene expression (Schmittgen and Livak, 2008). For each sample, the difference $(\mathrm{dCt})$ was calculated between $\mathrm{Ct}$ values obtained for target and reference amplicons. Comparative $\mathrm{ddCt}$ was then determined using as a reference the dCT calculated for the vehicle control samples $\left(\mathrm{EtOH}\right.$ for E2-treated samples and $\mathrm{H}_{2} \mathrm{O}$ for $\mathrm{Cd}$ 
and $\mathrm{Zn}$ ones), and absolute values for comparative expression level were determined as equal to $2^{\mathrm{ddCt}}$.

\section{Statistical Analysis}

The statistical analyses were performed using the Statview 4.57 software (Abacus Concepts Inc, Berkeley, CA). Kolmogorov-Smirnov test was used to check the normality assumption. For zfERs transactivation, differences among the experimental groups were assessed by oneway ANOVA, followed by protected least significant difference Fisher's test. To calculate the normalized relative gene expression levels (fold induction), and due to the absence of normal distribution, data were analyzed using the non-parametric Mann-Whitney $U$ test with Bonferroni correction for multiple comparisons. Values were considered to be significant when $\mathrm{P}<0.05$.

\section{Results}

\section{Dose-response effect of Cadmium Chloride on transcriptional activation of zfERs in U251-MG cells}

The effect of Cd was analyzed using the three ER isoforms and is represented as fold induction of luciferase activity in treated versus control samples. The maximum transcriptional response corresponding to $100 \%$ was assigned to the E2-treated group. As shown in Figure 1, the three zebrafish ERs were unable to induce the transcriptional activity of the reporter gene in the presence of Cd alone (Figure 1A). However, Cd caused a clear dose-dependent inhibition of the E2-induced luciferase activity in the U251-MG cells transfected with the three ER subtypes (Figure 1B). A Cd concentration of $10^{-6} \mathrm{M}$, corresponding to a 50\% inhibition of the maximal E2 effect, was chosen for subsequent analyses and studies.

\section{Effect of Zn supplementation on zfERS transactivation in U251-MG cells}

The effects obtained with the different $\mathrm{Zn}$ concentrations are reported in Figure 2A. The data show that $\mathrm{Zn}$ is able to reverse, in a dose-dependent manner, the inhibitory effects of $\mathrm{Cd}$ on E2 up-regulation of the reporter gene. As shown in the Figure 2A, the induction of the reporter gene ERE-TK-luc was stronger for the highest concentration of $\mathrm{Zn}\left(10^{-5} \mathrm{M}\right)$ causing a 70 to 100 fold induction depending on the ER subtype compared to the E2+Cd-treated cells. Treatment with $\mathrm{Zn}$ alone had no effect (Figure 2B).

\section{Effects of $\mathrm{Cd}$ and $\mathrm{Zn}$ on the E2-induced aromatase B protein expression in zebrafish}

Results regarding in vivo Aro-B expression in the zebrafish brain are shown in Figure 3. E2treated embryos, used as a positive control in these experiments, exhibited a very strong expression of the aromatase $\mathrm{B}$ in the radial glial cells (RGC) (Figure 3B). In contrast, control EtOH-treated group displayed no significant signal (Figures 3A). However, as seen in Figure 3C, co-treatment with Cd strongly decreased the intensity of the aromatase B staining. Indeed, only a few labeled cells were observed corresponding to RGC based on their typical 
morphology: small nucleus along the ventricules and long cytoplasmic processes. Interestingly, Zn supplementation was able to reverse this effect resulting in a strong staining in RGC immunoreactive cells. The pattern of aromatase B labeling observed in E2+Cd+Zntreated embryos was very similar to that observed in E2-treated group (Figure 3D).

To confirm these data the E2-responsive transgenic tg(cyp19a1b-GFP) zebrafish line was used. Figure 3F shows that E2 treatment of embryos caused a massive expression of GFP in RGC compared to the EtOH control group (Figure 3E). As previously, Cd treatment inhibits GFP E2-induced expression in RGC (Figure 3G) and $\mathrm{Zn}$ was able to reverse this effect (Figure 3H).

\section{Effects of $\mathrm{Cd}$ and $\mathrm{Zn}$ on the E2-induced cyp19a1b transcripts in zebrafish embryos}

Figure 4 shows the mRNA levels of the cyp19alb gene measured by reverse transcription real-time quantitative experiments (RT-qPCR) in zebrafish embryos after treatment with E2, $\mathrm{Cd}$ and/or $\mathrm{Zn}$. There was no significant effect of $\mathrm{Zn}$ or $\mathrm{Cd}$ alone (Figure 4B). However, as expected, E2 robustly stimulated the expression of the cyp19alb gene (Figure 4A), resulting in a fold induction of thirty-eight times compared to the control condition (EtOH). Cotreatment with E2 and Cd resulted in a significant inhibition of the E2-induced cyp 19alb mRNA levels (Figure 4A) while, surprisingly, supplementation with $\mathrm{Zn}$ has no significant effect.

\section{Effects of Cd and Zn on esr1, esr2a, and esr $2 b$ mRNAs in zebrafish embryos}

Figure 5A shows that a significant increase in esrl, esr2a and esr2b transcripts occurred after E2 treatment. However, this effect was more obvious on esrl messengers (3.53 fold) compared to esr $2 a$ (1.54 fold) and esr $2 b$ (1.80 fold). These actions were totally abolished by co-treatment with $\mathrm{Cd}$, but $\mathrm{Zn}$ supplementation did not reverse the inhibitory impact of $\mathrm{Cd}$ (Figure 5A). Exposure to $\mathrm{Cd}$ and $\mathrm{Zn}$ alone did not affect ERs gene (Figure 5B).

\section{Discussion}

During the past years, many scientists have reported evidence that environmental contaminants such as organochlorine pesticides, polychlorinated biphenyls and heavy metals could bioaccumulate in different areas of the brain and significantly affect neuroendocrine systems. This led to the concept of neuroendocrine disruptors which are defined as environmental pollutants capable of modulating the synthesis, metabolism or action of neurohormones, impacting then physiological or behavioral processes in humans or animals (León-Olea et al., 2014). The brain is considered as an organ highly sensitive to heavy metals such as mercury, lead and $\mathrm{Cd}$, which are well known to affect brain development in mammals including humans (Genuis and Kelln, 2015 ; Grandjean and Landrigan, 2014). However little is known about the potential effects of heavy metals in fish. Thus, the aim of the present work was to study the effects on the transcriptional activation of zfERs as well as the Aro-B expression after exposure of culture cells and zebrafish embryos to $\mathrm{Cd}$, individually or in mixture with E2, and supplemented or not with Zn. 
Our results showed that zfERs were unable to promote a transcriptional response of the E2target gene, in vitro nor in vivo, after $\mathrm{Cd}$ exposure. However, a number of previous reports showed that $\mathrm{Cd}$ exerts characteristic effects of the endogenous steroid hormone, E2, such as activation of the human ER $\alpha$ and induction of proliferation of MCF7 breast cancer cells (Brama et al., 2007 ; Garcia-Morales et al., 1994). Stoica et al. (2000) found that cadmium chloride at $10^{-6} \mathrm{M}$ was as potent as $10^{-9} \mathrm{M}$ E2 in activating the ER ; result which we and others (Silva et al., 2006) failed to obtain for the same concentrations tested. Moreover, according to the data here presented, this heavy metal seems to completely abolish the E2induction of the reporter gene in a dose-dependent manner and for the three ER subtypes, thus suggesting an E2-antagonism. These findings are in perfect agreement with those obtained by Le Guével et al. (2000) who observed that Cd inhibited the transcriptional activity of E2activated ER in yeast cells transfected either with the rainbow trout or the human ER and who showed that this metal did not induce activation of any receptor when tested alone.

However, it is important to emphasize that not all estrogenic chemicals disrupt the endocrine system through binding to specific nuclear ERs since estrogens can also signal through a non classical genomic pathway. EDs-indirect effects can thus be considered as the disruption of the action of enzymes involved in steroidogenesis (Kerdivel et al., 2013). For instance, different substances from diverse chemical families have been shown to disrupt aromatase (Monod et al., 1993 ; Rocha Monteiro et al., 2000 ; Sanderson et al., 2002), a crucial enzyme which converts androgens into estrogens. In fact, the brain of adult teleost fish is well known for its high aromatase activity (Pellegrini et al., 2005) corresponding to the strong expression of the cyp19alb gene, that encodes CYP19A1B (or Aro-B), the brain form of aromatase in fish (Tchoudakova et al., 2001). It was indicated that this gene can be used as a sensitive marker of the effects of xenoestrogens in zebrafish early life stages (Hinfray et al., 2006 ; Le Page et al., 2006). In our investigation, we demonstrated, by both RT-qPCR and immunohistochemistry, that E2 treatment causes strong induction of Aro-B in RGC of zebrafish embryos. This result was further strengthened by the use of the cyp19alb-GFP transgenic zebrafish carrying the green fluorescent Aro-B as indicator of protein expression in live embryos. This line strongly and faithfully expresses Aro-B in the same cellular context after E2 treatment (Tong et al., 2009). Accordingly, several studies have also noted such observations reporting that cyp19alb gene in fish brain is up-regulated by E2 through a positive feedback loop (Callard et al., 2001), an effect that involves ER and an ERE sequence localized on the proximal promoter of the cyp19alb gene (Menuet et al., 2005 ; Le Page et al., 2008). Additionally, our results further confirm that aromatase expression is extremely cell specific since it is strictly restricted to RGC as previously documented (Forlano et al., 2001 ; Menuet et al., 2003). These cells are well known for being crucial in brain development or brain repair. They are considered as progenitor cells ultimately capable of generating all brain cell types during embryogenesis before disappearing in mammalian adults (Bonfanti and Peretto, 2007 ; Malatesta et al., 2008) whereas they largely persist in adult fish (Arochena et al., 2004). This characteristic could be related to the capacity of the fish brain to grow and regenerate during adulthood (Ekström et al., 2001). After exposure of wild-type and transgenic zebrafish to both $\mathrm{E} 2$ and $\mathrm{Cd}$, Aro-B protein and transcripts were found to be significantly down-regulated comparing to E2-treated embryos. Such a result was noted by Menuet et al. (2005) who showed that the E2-dependent induction of the cyp19a1b was entirely blocked by co-treatment with E2 and an excess of the pure antagonist, ICI $_{182-780}$ indicating that functional ERs were involved. This was further evidenced by the fact that the promoter of the zebrafish cyp19 gene was shown to contain a $1 / 2$ ERE and an ERE putative site (Callard et al., 2001 ; Tong and Chung, 2003). 
Based on these observations and considering our results on transcriptional activation and Aro-B expression, we may speculate that $\mathrm{Cd}$ could have a direct effect on zfERs, thus affecting Aro-B expression. As well known, many effects of this heavy metal action result from interaction with essential elements, such as Zn (Brzóska et al., 2007 ; Waalkes, 1986), a metal of great importance required for gene transcription and cofactor of many essential enzymes (Coleman, 1992 ; Vallee and Falchuk, 1993). It is also known as an ER-component. Predki and Sarkar (1992) showed that the Zn finger motif can be affected by some other metals having the ability to substitute for $\mathrm{Zn}$ such as copper, $\mathrm{Cd}$, cobalt and nickel. In this regard, it has been reported that the effects of $\mathrm{Cd}$ could reflect a disruption of $\mathrm{Zn}$ binding in the DBD by a competition process (Le Guével et al., 2000). Hence, given the ability of this heavy metal to compete and to replace $\mathrm{Zn}$, we thought that the supplement of this oligoelement could provide some corrections. Indeed, several studies, in fish and mammals, have pointed that the treatment with $\mathrm{Zn}$ during $\mathrm{Cd}$ exposure prevented or decreased the harmful effects of Cd in different tissues (Banni et al., 2011 ; Chouchene et al., 2011 ; El Heni et al., 2010 ; Messaoudi et al., 2010). Consistent with these reports, the current study has shown that $\mathrm{Zn}$ supplement totally reversed the complete abolition by $\mathrm{Cd}$ of the E2-stimulatory effects on ERE-TK-luc activity as well as Aro-B protein expression in wild-type and transgenic zebrafish. Furthermore, quantification of the GFP expression in the tg-(cyp19albGFP) zebrafish in multiple field of view mode was performed as previously reported (Brion et al., 2012) and confirmed the protective effect of $\mathrm{Zn}$ (data not shown). Although $\mathrm{Zn}$ concentrations were not measured in fish and culture cells used in this study, it is possible that the protection provided by this oligoelement against $\mathrm{Cd}$-induced toxicity might result from an increase of $\mathrm{Zn}$ availability due to $\mathrm{Zn}$ supplementation as reported by some authors (Chemek et al., 2015 ; Chouchene et al., 2011). The correction observed at the zfERs transactivation level leads to think that the $\mathrm{Zn}$ finger motifs could be involved at first in Cd toxicity and later in $\mathrm{Zn}$ protection. Indeed, the DBD coordinates two $\mathrm{Zn}$ ions with cysteine residues into $\mathrm{Zn}$ finger motifs (Evans, 1988 ; Pike, 2006). We hypothesize that Cd is able to interact with the ER, after its activation by E2, by competing with $\mathrm{Zn}$ in the DNA binding domain, suggested as a putative site of Cd action (Le Guével et al., 2000), impeding thus the transformation of the ER to a DNA-binding form. This then reduces the interaction of activated ER with DNA and subsequent transcriptional activity. This idea was also supported by Silva et al. (2006), while other investigators reported a second mechanistic explanation suggesting that $\mathrm{Cd}$ binds with a high affinity to the LBD of ER $\alpha$ by forming a coordination complex with amino-acid residues, which blocks the binding of E2 (Stoica et al., 2000). Additionally, our results demonstrate that $\mathrm{Zn}$ at $10^{-5} \mathrm{M}$ did not induce activation of any receptor when tested alone. This shows that Zn-protective effect could not have been masked by its ability to be E2mimetic, and further proves that $\mathrm{Zn}$ effect requires interaction with $\mathrm{Cd}$.

Parallely and as previously stated, E2-dependent regulation of aromatase involves a direct transcriptional action of ERs requiring the synergistic effect of ERE and $1 / 2$ ERE in the promoter region of the cyp19b gene (Menuet et al., 2005). On this basis and given Cd effects reported herein, it can be hypothesized that this heavy metal is able to affect Aro-B expression in the brain, indirectly, through competing with $\mathrm{Zn}$ at the ER level. This assumption is further reinforced by the fact that the improvement of ERs transactivation level after $\mathrm{Zn}$ exposure was accompanied by a strong Aro-B protein expression. But surprisingly, the ameliorative effect of $\mathrm{Zn}$ supplement was not observed using RT-qPCR, whilst a significant up-regulation was expected. This result leads us to suggest a second hypothesis supporting the idea that $\mathrm{Zn}$ could also exert its protective effect by interacting with the toxic metal $\mathrm{Cd}$ at the protein level stabilizing thus the protein. Indeed, it is well known that the presence of $\mathrm{Cd}$ in the organism decreases the iron (Fe) level in several tissues (Jurczuk et al., 2004). Since Aro-B is a 
hemeprotein with Fe-containing site (Favia et al., 2006 ; Hong et al., 2009), the decreased induction of the enzyme in the zebrafish brain exposed to $\mathrm{Cd}$ might be a result of protein inactivation due to $\mathrm{Fe}$ deficiency. The strong induction of Aro-B revealed by immunohistochemistry after $\mathrm{Zn}$ supplementation could thus be explained by a protein stabilization since the activity of a large number of enzymes depends on a sufficient supply of trace elements, such as Zn, selenium and copper (Rükgauer et al., 2001). Given the results herein presented and in addition to the well-documented effects of heavy metals, notably $\mathrm{Cd}$, on thyroid signaling and brain development (Grandjean and Landrigan, 201), it is also possible that neuroendocrine disruption occurs through interactions with estrogen signaling.

In summary, the present study describes $\mathrm{Cd}$ as a potent anti-estrogen in vivo and in vitro and provides evidence that this heavy metal inhibits estrogen action in the developing zebrafish brain, as demonstrated by inhibition of E2-induction of Aro-B. The effect of Cd on the Aro-B expression in the radial glial cells at early developmental stages can therefore affect the neuroendocrine system and the reproductive function. While the precise mechanisms remain to be elucidated, our data would suggest that $\mathrm{Cd}$ effects on estrogen signaling in the brain could be, in part, due to interference with classical nuclear ER subtypes affecting then Aro-B expression. Our results further demonstrated that $\mathrm{Zn}$ supplement provides an ameliorative effect against E2-antagonism of Cd in zebrafish embryos and U251-MG cells as evidenced by the improvement of the protein expression of Aro-B and the enhancement of ERstranscriptional activation level. However, the exact mechanisms underlying the protective effect of $\mathrm{Zn}$ on the neuroendocrine system need to be fully clarified.

\section{Acknowledgements}

This work was supported, in part, by grants from the Ministry of Higher Education, Scientific Research and Technology of Tunisia, the French Ministry of Ecology, Energy and Sustainable Development (PNRPE project MIXEZ 11-MRES-PNRPE-7-CVS-033) and "Rennes Metropole (France)". We are thankful for INSERM and University of Rennes 1 (France) for funding our research. The valuable assistance of the staff of the zebrafish facilities (INRA) is also greatly appreciated.

\section{References}

Amara S, Abdelmelek H, Garrel C, Guiraud P, Douki T, Ravanat JL, Favier A, Sakly M, Ben Rhouma K. 2008. Preventive effect of zinc against cadmium-induced oxidative stress in the rat testis. J. Reprod. Dev. 54: 129-134.

Arochena M, Anadón R, Díaz-Regueira SM. 2004. Development of vimentin and glial fibrillary acidic protein immunoreactivities in the brain of gray mullet (Chelon labrosus), an advanced teleost. J. Comp. Neurol. 469: 413-436.

Banni M, Chouchene L, Said K, Kerkeni A, Messaoudi I. 2011. Mechanisms underlying the protective effect of zinc and selenium against cadmium-induced oxidative stress in zebrafish Danio rerio. Biometals. 24: 981-992. 
Bonfanti L, Peretto P. 2007. Radial glial origin of the adult neural stem cells in the subventricular zone. Prog. Neurobiol. 83: 24-36.

Brama M, Gnessi L, Basciani S, Cerulli N, Politi L, Spera G, Mariani S, Cherubini S, Scotto d'Abusco A, Scandurra R, Migliaccio S. 2007. Cadmium induces mitogenic signaling in breast cancer cell by an ER $\alpha$-dependent mechanism. Mol. Cell. Endocrinol. 264: 102-108.

Bridges CC, and Zalups RK. 2005. Molecular and ionic mimicry and the transport of toxic metals. Toxicol. Appl. Pharmacol. 204: 274-308.

Brion F, Le Page Y, Piccini B, Cardoso O, Tong SK, Chung BC, Kah O. 2012. Screening estrogenic activities of chemicals or mixtures in vivo using transgenic (cyp19alb-GFP) zebrafish embryos. PLoS ONE. 7: e36069. DOI: 10.1371/journal.pone.0036069.

Brzóska MM, Rogalska J, Galazyn-Sidorczuk M, Jurczuk M, Roszczenko A, KulikowskaKarpińska E, Moniuszko-Jakoniuk J. 2007. Effect of zinc supplementation on bone metabolism in male rats chronically exposed to cadmium. Toxicology. 237: 89-103.

Brzóska MM, Moniuszko-Jakoniuk J. 2001. Interactions between cadmium and zinc in the organism. Food. Chem. Toxicol. 39: 967-980.

Callard GV, Tchoudakova AV, Kishida M, Wood E. 2001. Differential tissue distribution, developmental programming, estrogen regulation and promoter characteristics of cyp19 genes in teleost fish. J. Steroid. Biochem. Mol. Biol. 79: 305-314.

Carreau S. 2002. The testicular aromatase: from gene to physiological role. Reprod. Biol. 2: $5-12$.

Chemek M, Boughammoura S, Ben Mimouna S, Chouchene L, Banni M, Messaoudi I. 2015. Changes of the mRNA expression pattern of $\mathrm{Zn}$ transporters: a probable mechanism for cadmium retention and zinc redistribution in the suckling rat tissues. Biol. Trace. Elem. Res. 165: $173-182$.

Chouchene L, Banni M, Kerkeni A, Saïd K, Messaoudi I. 2011. Cadmium-induced ovarian pathophysiology is mediated by change in gene expression pattern of zinc transporters in zebrafish (Danio rerio). Chem. Biol. Interact. 193: 172-179.

Coleman JE. 1992. Zinc proteins: enzymes, storage proteins, transcription factors, and replication proteins. Annu. Rev. Biochem. 61: 897-946.

Diotel N, Le Page Y, Mouriec K, Tong SK, Pellegrini E, Vaillant C, Anglade I, Brion F, Pakdel F, Chung BC, Kah O. 2010. Aromatase in the brain of teleost fish: expression, regulation and putative functions. Front. Neuroendocrinol. 31: 172-192.

Ekström P, Johnsson CM, Ohlin LM. 2001. Ventricular proliferation zones in the brain of an adult teleost fish and their relation to neuromeres and migration (secondary matrix) zones. $J$. Comp. Neurol. 436: 92-110. 
El Heni J, Hammouda F, Allègue N, Messaoudi I, Kerkeni A. 2010. Cadmium retention increase: A probable key mechanism of the protective effect of zinc on cadmium-induced toxicity in the kidney. Toxicol. Lett. 196: 104-109.

Evans RM. 1988. The steroid and thyroid hormone receptor superfamily. Science. 240: 889895.

Fahmy MA, Aly FA. 2000. In vivo and in vitro studies on the genotoxicity of cadmium chloride in mice. J. Appl. Toxicol. 20: 231-238.

Favia AD, Cavalli A, Masetti M, Carotti A, Recanatini M. 2006. Three-dimensional model of the human aromatase enzyme and density functional parameterization of the iron-containing protoporphyrin IX for a molecular dynamics study of heme-cysteinato cytochromes. Proteins. 62: 1074-1087.

Forlano PM, Deitcher DL, Myers DA, Bass AH. 2001. Anatomical distribution and cellular basis for high levels of aromatase activity in the brain of teleost fish: aromatase enzyme and mRNA expression identify glia as source. J. Neurosci. 21: 8943-8955.

Garcia-Morales P, Saceda M, Kenney N, Kim N, Salomon DS, Gottardis MM, Solomon HB, Sholler PF, Jordan VC, Martin MB. 1994. Effect of cadmium on estrogen receptor levels and estrogen-induced responses in human breast-cancer cells. J. Biol. Chem. 269: 1689616901.

Genuis SJ, Kelln KL. 2015. Toxicant exposure and bioaccumulation: a common and potentially reversible cause of cognitive dysfunction and dementia. Behav. Neurol. 2015: 620143.

Grandjean P, Landrigan PJ. 2014. Neurobehavioural effects of developmental toxicity. Lancet Neurol. 13: 330-338.

Hinfray N, Palluel O, Turies C, Cousin C, Porcher JM, Brion F. 2006. Brain and gonadal aromatase as potential targets of endocrine disrupting chemicals in a model species, the zebrafish (Danio rerio). Environ. Toxicol. 21: 332-337.

Hong Y, Li H, Yuan YC, Chen S. 2009. Molecular characterization of aromatase. Ann. N.Y. Acad. Sci. 1155: 112-120.

Jemai H, Messaoudi I, Chaouch A, Kerkeni A. 2007. Protective effect of zinc supplementation on blood antioxidant defense system in rats exposed to cadmium. J. Trace Elem. Med. Biol. 21: 269-273.

Johnson MD, Kenney N, Stoica A, Hilakivi-Clarke L, Singh B, Chepko G, Clarke R, Sholler PF, Lirio AA, Foss C, Reiter R, Trock B, Paik S, Martin MB. 2003. Cadmium mimics the in vivo effects of estrogen in the uterus and mammary gland. Nat. Med. 9: 1081-1084.

Jurczuk M, Brzóska MM, Moniuszko-Jakoniuk J, Gałazyn-Sidorczuk M, KulikowskaKarpińska E. 2004. Antioxidant enzymes activity and lipid peroxidation in liver and kidney of rats exposed to cadmium and ethanol. Food Chem. Toxicol. 42: 429-438. 
Kerdivel G, Habauzit D, Pakdel F. 2013. Assessment and molecular actions of endocrinedisrupting chemicals. Int. J. Endocrinol. 501851. DOI: 10.1155/2013/501851.

Kime DE. 1984. The effect of cadmium on steroidogenesis by testes of the rainbow trout, Salmo gairdneri. Toxicol. Lett. 22: 83-88.

Lafuente A, Cano P, Esquifino A. 2003. Are cadmium effects on plasma gonadotropins, prolactin, ACTH, GH and TSH levels, dose-dependent? Biometals. 16: 243-250.

Lansdown AB, Sampson B, Rowe A. 2001. Experimental observations in the rat on the influence of cadmium on skin wound repair. Int. J. Exp. Pathol. 82: 35-41.

Le Guével R, Petit FG, Le Goff P, Métivier R, Valotaire Y, Pakdel F. 2000. Inhibition of rainbow trout (Oncorhynchus mykiss) estrogen receptor activity by cadmium. Biol. Reprod. 63: $259-266$.

Le Page Y, Menuet A, Kah O, Pakdel F. 2008. Characterization of a cis-acting element involved in cell-specific expression of the zebrafish brain aromatase gene. Mol. Reprod. Dev. 75: $1549-1557$.

Le Page Y, Scholze M, Kah O, Pakdel F. 2006. Assessment of xenoestrogens using three distinct estrogen receptors and the zebrafish brain aromatase gene in a highly responsive glial cell system. Environ. Health Perspect . 114: 752-758.

León-Olea M, Martyniuk CJ, Orlando EF, Ottinger MA, Rosenfeld CS, Wolstenholme JT, Trudeau VL. 2014. Current concepts in neuroendocrine disruption. Gen. Comp. Endocrinol. 203:158-173.

Malatesta P, Appolloni I, Calzolari F. 2008. Radial glia and neural stem cells. Cell Tissue Res. 331: $165-178$.

Martin MB, Reiter R, Pham T, Avellanet YR, Camara J, Lahm M, Pentecost E, Pratap K, Gilmore BA, Divekar S, Dagata RS, Bull JL, Stoica A. 2003. Estrogenlike activity of metals in MCF-7 breast cancer cells. Endocrinology. 144: 2425-2436.

Menuet A, Anglade I, Le Guével R, Pellegrini E, Pakdel F, Kah O. 2003. Distribution of aromatase mRNA and protein in the brain and pituitary of female rainbow trout: comparison with estrogen receptor alpha. J. Comp. Neurol. 462: 180-193.

Menuet A, Pellegrini E, Anglade I, Blaise O, Laudet V, Kah O, Pakdel F. 2002. Molecular characterization of three estrogen receptor forms in zebrafish: binding characteristics, transactivation properties, and tissue distributions. Biol. Reprod. 66: 1881-1892.

Menuet A, Pellegrini E, Brion F, Gueguen MM, Anglade I, Pakdel F, Kah O. 2005. Expression and estrogen-dependent regulation of the zebrafish brain aromatase gene. $J$. Comp. Neurol. 485: 304-320.

Messaoudi I, Banni M, Saïd L, Saïd K, Kerkeni A. 2010. Evaluation of involvement of testicular metallothionein gene expression in the protective effect of zinc against cadmiuminduced testicular pathophysiology in rat. Reprod. Toxicol. 29: 339-345. 
Métivier R, Stark A, Flouriot G, Hübner MR, Brand H, Penot G, Manu D, Denger S, Reid G, Kos M, Russell RB, Kah O, Pakdel F, Gannon F. 2002. A dynamic structural model for estrogen receptor-alpha activation by ligands, emphasizing the role of interactions between distant A and E domains. Mol. Cell. 10: 1019-1032.

Moggs JG, Orphanides G. 2001. Estrogen receptors: orchestrators of pleiotropic cellular responses. EMBO Rep. 2: 775-781.

Monod G, De Mones A, Fostier A. 1993. Inhibition of ovarian microsomal aromatase and follicular estradiol secretion by imidazole fungicides in Rainbow Trout. Mar. Environ. Res. 35: 153-157.

Mouriec K, Gueguen MM, Manuel C, Percevault F, Thieulant ML, Pakdel F, Kah O. 2009a. Androgens upregulate cyp19alb (aromatase B) gene expression in the brain of zebrafish (Danio rerio) through estrogen receptors. Biol Reprod. 80: 889-896.

Mouriec K, Lareyre JJ, Tong SK, Le Page Y, Vaillant C, Pellegrini E, Pakdel F, Chung BC, Kah O, Anglade I. 2009b. Early regulation of brain aromatase (cyp19a1b) by estrogen receptors during zebrafish development. Dev Dyn. 238: 2641-2651.

Mukherjee D, Kumar V, Chakraborti P. 1994. Effect of mercuric chloride and cadmium chloride on gonadal function and its regulation in sexually mature common carp Cyprinus carpio. Biomed. Environ. Sci. 7: 13-24.

Parizek J, Zahor Z. 1956. Effect of cadmium salts on testicular tissue. Nature. 177: 1036.

Pellegrini E, Menuet A, Lethimonier C, Adrio F, Gueguen MM, Tascon C, Anglade I, Pakdel F, Kah O. 2005. Relationships between aromatase and estrogen receptors in the brain of teleost fish. Gen. Comp. Endocrinol. 142: 60-66.

Pellegrini E, Mouriec K, Anglade I, Menuet A, Le Page Y, Gueguen MM, Marmignon MH, Brion F, Pakdel F, Kah O. 2007. Identification of aromatase-positive radial glial cells as progenitor cells in the ventricular layer of the forebrain in zebrafish. J. Comp. Neurol. 501: $150-167$.

Piasek M, Blanusa M, Kostial K, Laskey JW. 2001. Placental cadmium and progesterone concentrations in cigarette smokers. Reprod. Toxicol. 15: 673-681.

Piasek M, Laskey JW. 1999. Effects of in vitro cadmium exposure on ovarian steroidogenesis in rats. J. Appl. Toxicol. 19: 211-217.

Pike AC. 2006. Lessons learnt from structural studies of the oestrogen receptor. Best Pract. Res. Clin. Endocrinol. Metab. 20: 1-14.

Predki PF, Sarkar B. 1992. Effect of replacement of "zinc finger" zinc on estrogen-receptor DNA interactions. J. Biol. Chem. 267: 5842-5846.

Rocha Monteiro PR, Reis-Henriques MA, Coimbra J. 2000. Polycyclic aromatic hydrocarbons inhibit in vitro ovarian steroidogenesis in the flounder (Platichthys flesus L.). Aquat. Toxicol. 48: 549-559. 
Rükgauer M, Neugebauer RJ, Plecko T. 2001. The relation between selenium, zinc and copper concentration and the trace element dependent antioxidative status. J. Trace Elem. Med. Biol. 15: 73-78.

Sanderson JT, Boerma J, Lansbergen GW, Van Den Berg M. 2002. Induction and inhibition of aromatase (CYP19) activity by various classes of pesticides in H295R human adrenocortical carcinoma Cells. Toxicol. Appl. Pharmacol. 182: 44-54.

Schmittgen TD, Livak KJ. 2008. Analyzing real-time PCR data by the comparative C(T) method. Nat. Protoc. 3: 1101-1108.

Silva E, Lopez-Espinosa MJ, Molina-Molina JM, Fernández M, Olea N, Kortenkamp A. 2006. Lack of activity of cadmium in in vitro estrogenicity assays. Toxicol. Appl. Pharmacol. 216: $20-28$.

Stoica A, Katzenellenbogen BS, Martin MB. 2000. Activation of estrogen receptor- $\alpha$ by the heavy metal cadmium. Mol. Endocrinol. 14: 545-553.

Tchoudakova A, Kishida M, Wood E, Callard GV. 2001. Promoter characteristics of two cyp19 genes differentially expressed in the brain and ovary of teleost fish. J. Steroid Bioch. Mol. Biol. 78: 427-439.

Thompson J, Bannigan J. 2008. Cadmium: toxic effects on the reproductive system and the embryo. Reprod. Toxicol. 25: 304-315.

Tong SK, Chung BC. 2003. Analysis of zebrafish cyp19 promoters. J. Steroid. Biochem. Mol. Biol. 86: 381-386.

Tong SK, Mouriec K, Kuo MW, Pellegrini E, Gueguen MM, Brion F, Kah O, Chung BC. 2009. A cyp19alb-gfp (aromatase B) transgenic zebrafish line that expresses GFP in radial glial cells. Genesis. 47: 67-73.

Vallee BL, Falchuk KH. 1993. The biochemical basis of zinc physiology. Physiol. Rev. 73: 79-118.

Waalkes MP. 1986. Effect of dietary zinc deficiency on the accumulation of cadmium and metallothionein in selected tissues of the rat. J. Toxicol. Environ. Health. 18: 301-313. 
Table 1: Sequences of the oligonucleotides used in Real Time Polymerase Chain Reaction experiments.

\begin{tabular}{lcl}
\hline Gene & Accession number & \multicolumn{1}{c}{ Sequence } \\
\hline esrl & NM_152959.1 & Fw: 5'-CTGGAGATGCTGGACGCTCA-3' \\
& & Rev: 5'-GCTGCAGCTCCTCCTCCTGG-3' \\
esr2a & NM_180966.2 & Fw: 5'-GATCCTCCTGAACTCCAACATG-3' \\
& & Rev: 5'-CCAGCAGACACAGCAGCTTGGA-3' \\
esr2b & NM_174862.3 & Fw: 5'-GATCCTGCTCAACTCTAATAAC-3' \\
& & Rev: 5'-CCAGCAGATTCAGCACCTTCCC-3' \\
cyp19alb & NM_131642.1 & Fw: 5'-TCGGCACGGCGTGCAACTAC-3' \\
& & Rev: 5'-CATACCTATGCATTGCAGACC-3' \\
ef1 & NM_131263.1 & Fw: 5'-AGCAGCAGCTGAGGAGTGAT-3' \\
& & Rev: 5'-CCGCATTTGTAGATCAGATGG-3' \\
\hline
\end{tabular}




\section{Figure Legends}
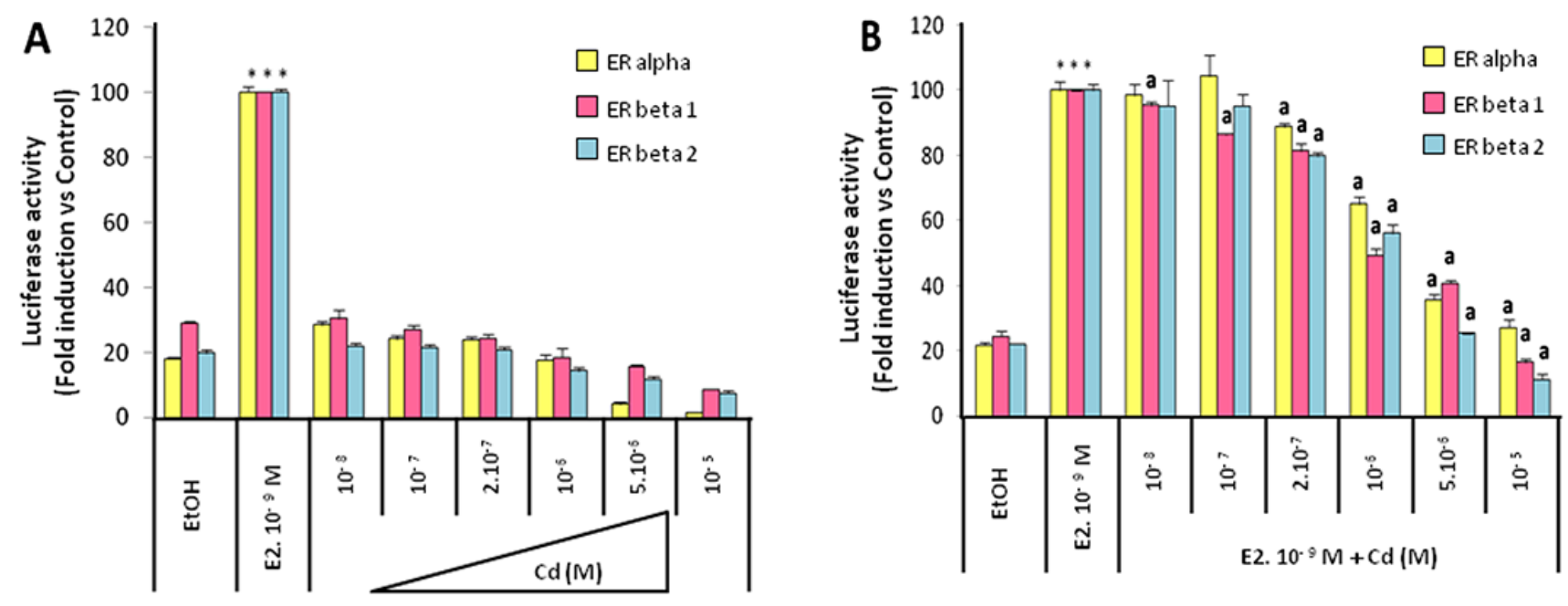

Figure 1: Evaluation of the transcriptional activation of the ERE-TK-luc reporter gene by the three zebrafish estrogen receptors in the presence of ethanol $(\mathrm{EtOH})$, estradiol (E2) and cadmium alone $(\mathrm{Cd})$ in figure $(\mathbf{A})$ and ethanol $(\mathrm{EtOH})$, estradiol (E2) and estradiol + cadmium together $(\mathrm{E} 2+\mathrm{Cd})$ in figure $(\mathbf{B})$. Data are the mean of at least three separate transfection experiments performed in triplicate. * and a indicate significant differences comparing to EtOH and E2-treated groups respectively ( $\mathrm{P}<0.05$ according to ANOVA test). 

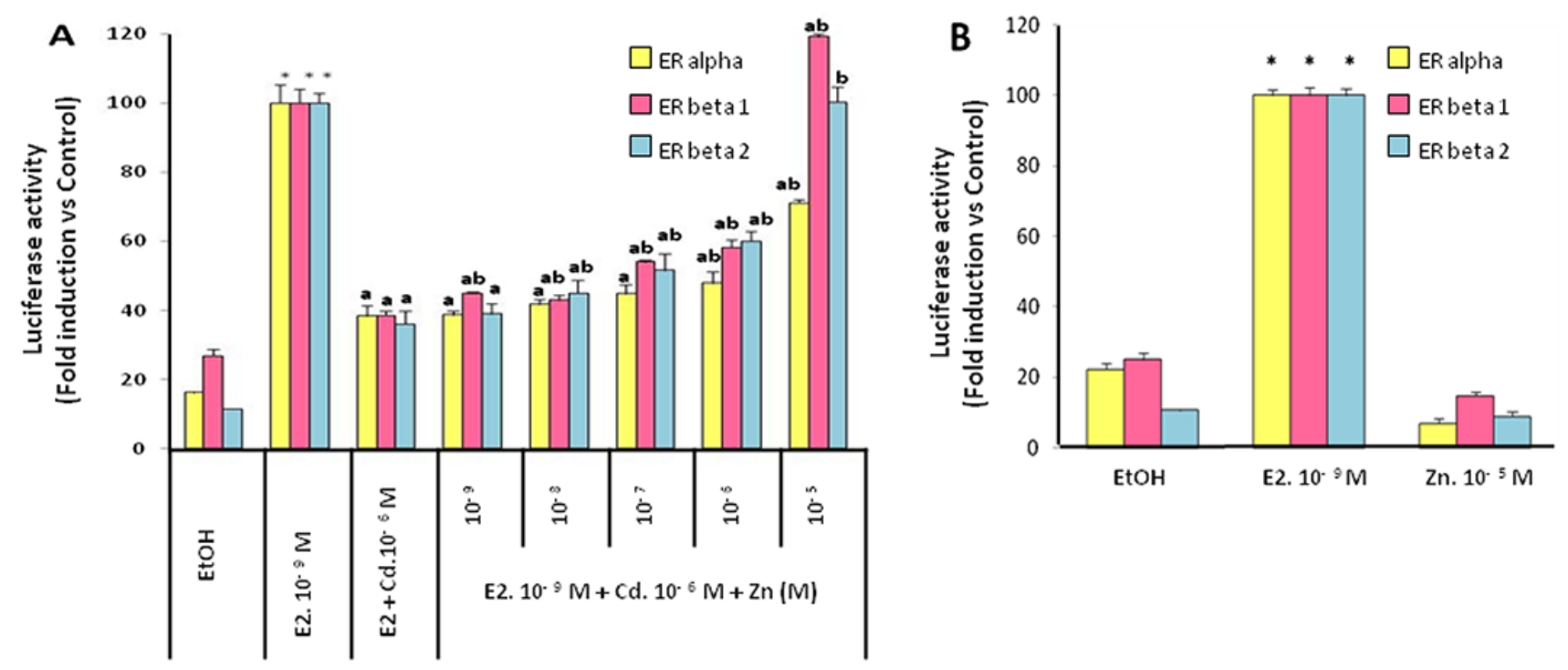

Figure 2: Evaluation of the transcriptional activation of the ERE-TK-luc reporter gene by the three zebrafish estrogen receptors in the presence of ethanol $(\mathrm{EtOH})$, estradiol (E2), estradiol + cadmium $(\mathrm{E} 2+\mathrm{Cd})$ and estradiol + cadmium + zinc $(\mathrm{E} 2+\mathrm{Cd}+\mathrm{Zn})$ in figure $(\mathrm{A})$ and ethanol $(\mathrm{EtOH})$, estradiol $(\mathrm{E} 2)$ and zinc alone $(\mathrm{Zn})$ in figure $(\mathbf{B})$. Data are the mean of at least three separate transfection experiments performed in triplicate. *, a and $\mathbf{b}$ indicate significant differences comparing to $\mathrm{EtOH}, \mathrm{E} 2$ and $\mathrm{E} 2+\mathrm{Cd}$-treated groups respectively $(\mathrm{P}<0.05$ according to ANOVA test). 


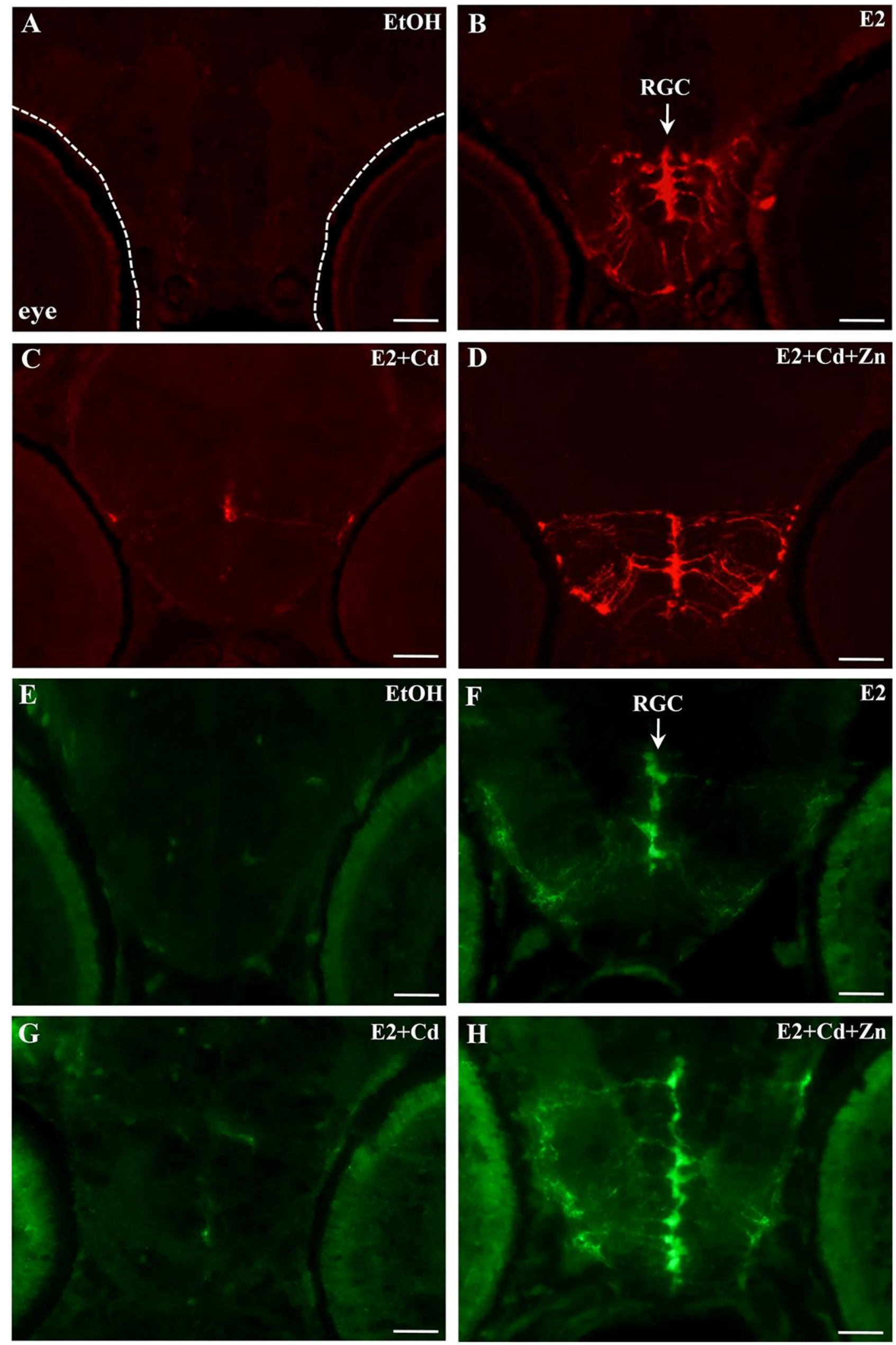


Figure 3: Transversal sections of the anterior hypothalamus of 3 days embryos showing aromatase B expression.

A, B, C and D : aromatase B immunoreactivity in radial glial cells (RGC) after exposure of wild-type zebrafish to ethanol $(\mathrm{A}, \mathrm{EtOH})$, estradiol $(\mathrm{B}, \mathrm{E} 2)$, estradiol + cadmium $(\mathrm{C}, \mathrm{E} 2+\mathrm{Cd})$ and estradiol + cadmium + zinc $(D, E 2+C d+Z n)$. Scale bar $=100 \mu \mathrm{m}$

E, F, G and H: GFP expression in RGC after exposure of cyp19alb-GFP transgenic zebrafish to ethanol $(\mathrm{E}, \mathrm{EtOH})$, estradiol $(\mathrm{F}, \mathrm{E} 2)$, estradiol + cadmium $(\mathrm{G}, \mathrm{E} 2+\mathrm{Cd})$ and estradiol + cadmium + zinc $(\mathrm{H}, \mathrm{E} 2+\mathrm{Cd}+\mathrm{Zn})$. Scale bar $=50 \mu \mathrm{m}$ 

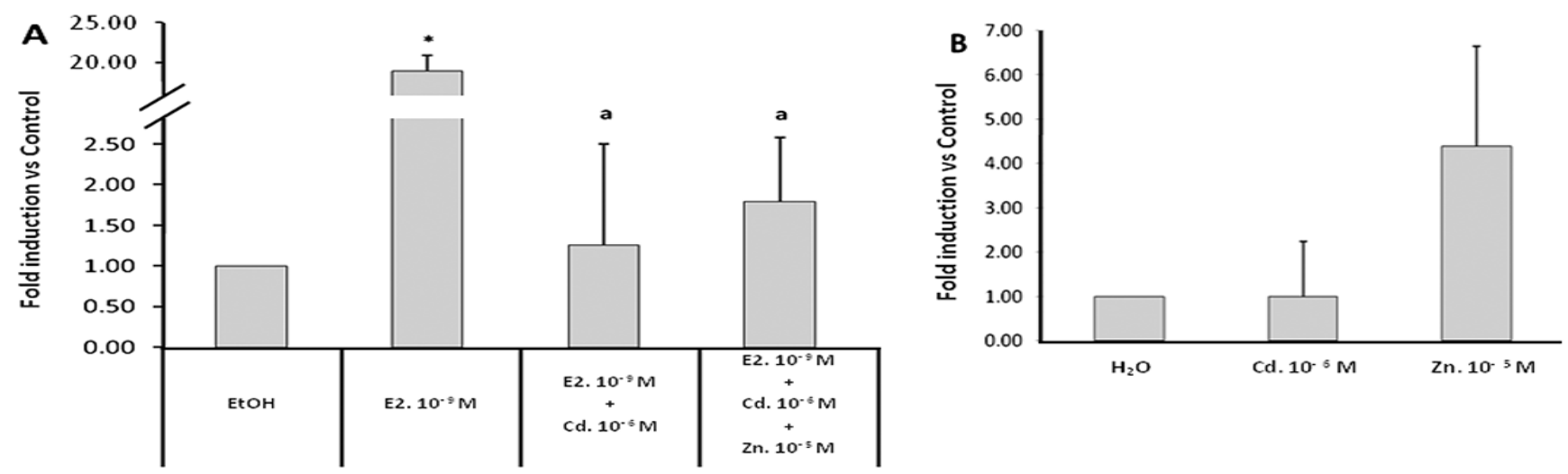

Figure 4: Expression of cyp19alb gene in zebrafish embryos exposed to ethanol (EtOH), estradiol (E2), estradiol + cadmium $(\mathrm{E} 2+\mathrm{Cd})$ and estradiol + cadmium + zinc $(\mathrm{E} 2+\mathrm{Cd}+\mathrm{Zn})$ in figure (A) and to distilled water $(\mathrm{H} 2 \mathrm{O})$, cadmium $(\mathrm{Cd})$ and zinc $(\mathrm{Zn})$ in figure $(\mathbf{B})$. The levels of Aro-B and efl transcripts were determined by quantitative reverse transcriptase-polymerase chain reaction (RT-qPCR) in $72 \mathrm{~h}$ postfertilization. The expression of efl mRNA was used as reference to normalize the expression levels of the studied gene mRNA. Data are expressed as fold induction relative to control and corresponds to the median of five independent exposure experiments performed in triplicate. ${ }^{*}$ and a indicate significant differences comparing to EtOH and E2-treated groups respectively ( $\mathrm{P}<0.05$ according to Mann-Whitney test corrected by Bonferroni correction). 

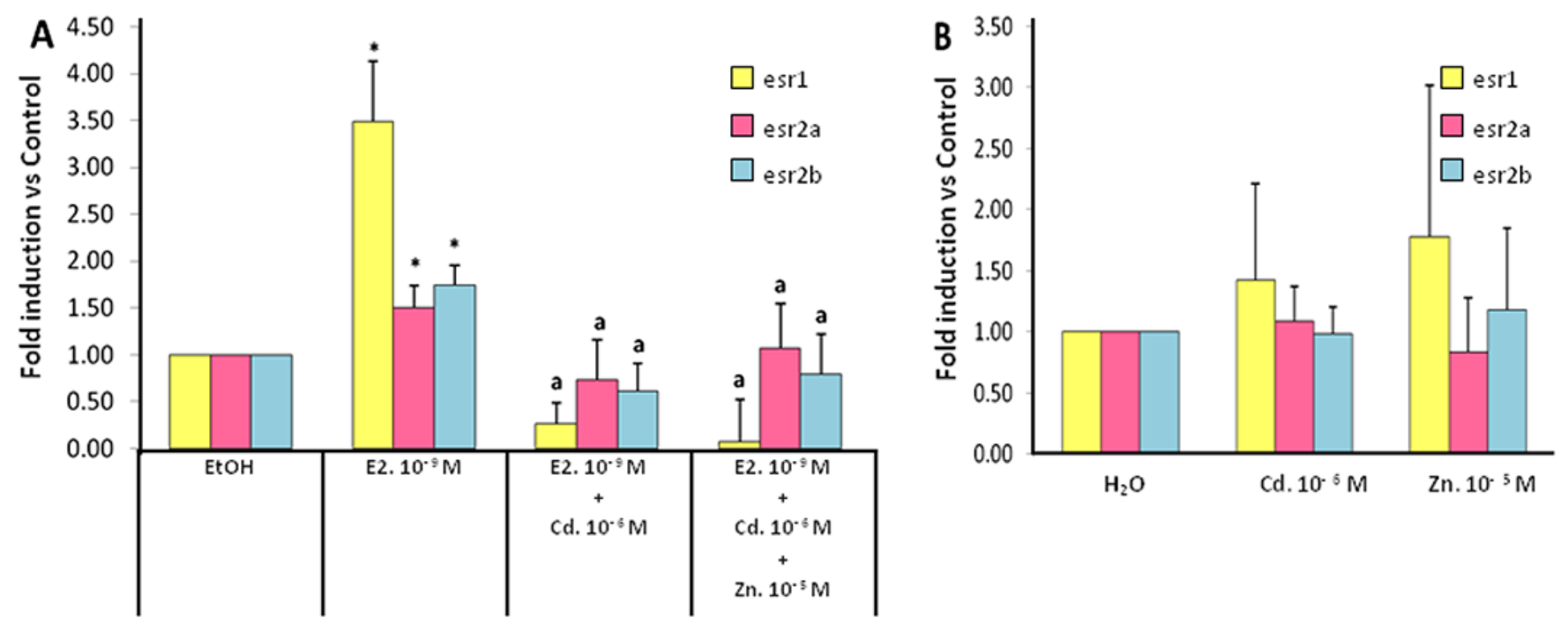

Figure 5: Expression of esrl, esr $2 a$ and $e s r 2 b$ genes in zebrafish embryos exposed to ethanol $(\mathrm{EtOH})$, estradiol $(\mathrm{E} 2)$, estradiol + cadmium $(\mathrm{E} 2+\mathrm{Cd})$ and estradiol + cadmium + zinc $(\mathrm{E} 2+\mathrm{Cd}+\mathrm{Zn})$ in figure $(\mathrm{A})$ and to distilled water $(\mathrm{H} 2 \mathrm{O})$, cadmium $(\mathrm{Cd})$ and zinc $(\mathrm{Zn})$ in figure (B). The levels of esrl, esr $2 a$, esr $2 b$ and efl transcripts were determined by quantitative reverse transcriptase-polymerase chain reaction (RT-qPCR) in $72 \mathrm{~h}$ postfertilization. The expression of efl mRNA was used as reference to normalize the expression levels of the studied gene mRNA. Data are expressed as fold induction relative to control and corresponds to the median of five independent exposure experiments performed in triplicate. ${ }^{*}$ and $\mathbf{a}$ indicate significant differences comparing to $\mathrm{EtOH}$ and E2-treated groups respectively ( $\mathrm{P}<0.05$ according to Mann-Whitney test corrected by Bonferroni correction). 